\title{
Suppression of the Formation of Large Pores in the Assimilated Parts of Sinter Produced Using Pisolitic Ores
}

\author{
Takaho OTOMO, Noboru TAGUCHI and Eiki KASAI ${ }^{1)}$
}

Mining College, Akita University, Tegata Gakuen-cho, Akita, Akita-ken, 010 Japan. 1) Institute for Advanced Materials Processing, Tohoku University, Katahira, Aoba-ku, Sendai, Miyagi-ken, 980-77 Japan.

(Received on March 21, 1996; accepted in final form on July 15, 1996)

\begin{abstract}
Sintering experiments were carried out in order to suppress the formation of large pores existed in the assimilated parts of sinter produced using pisolitic ores. A briquette consisted of disk-shaped pisolitic ore specimen as core particle and fine mixture of hematite ore and limestone as shell layer was used for the experiments. $\mathrm{CaO}$ concentration of the shell layer was varied in two levels, i.e., 10 and 26 mass $\%$. The influence of $\mathrm{CaO}$ concentration of the shell layer and heating rate on the performance of large pore formation during heating were examined by a microscopic observation. The mean diameter and the area fraction of pores existed in the assimilated part of specimen were also measured. The results obtained were as follows:

$\mathrm{By}$ increasing $\mathrm{CaO}$ concentration of the shell layer from 10 to 26 mass $\%$, the suppression of the large pore formation was achieved in terms of the decrease in both of the diameter and amount of pores.

The amount of pores decreased with decrease in heating rate over the temperature of melt-formation for both $\mathrm{CaO}$ concentration of the shell layer, but heating rate did not influence remarkably pore diameter.

It is clear that the suppressible effect of the increase in $\mathrm{CaO}$ concentration of the shell layer on the formation of large pores is resulted from both of the promotion of coalescence of bubbles and decrease in the bubble size possible to move in the melt due to lowering apparent viscosity of the melt formed during heating.
\end{abstract}

KEY WORDS: sintering; raw mixtures; pisolitic ore; assimilation; large pores; apparent viscosity of melt; move of bubble.

\section{Introduction}

It has been indicated in Japanese steel industries that the increasing use of high-goethite ores, which contain about 10 mass \% of combined water, is required as sinter feeds. ${ }^{1,2)}$ It has been pointed out that the use of these ores as the core of pseudo-particle leads to some problems such as decrease in the permeability of sintering bed and deterioration of properties of product sinter. ${ }^{3,4)}$ Particularly, use of pisolitic ores as the core particles promotes to form a layer accompanying large pores in the assimilated parts around them and it causes decreases in product yield and strength of sinter. ${ }^{3,5,6)}$

The authors ${ }^{7)}$ have examined the cause of the formation of large pores by experiments using briquettes and found that the origin of the pores is not water vapor generated by dissociation of combined water in the core particles but atmospheric gas existed in macro pores and/or cracks formed in the core particles. Furthermore, the authors ${ }^{7)}$ have also proposed a mechanism of the formation of large pores as follows: Gas liberates from macro pores and/or cracks in the core particles due to its volume expansion and assimilation of the core; The gas is caught as a large bubble in the melt with high viscosity formed around the core particles; Then, large pores form in the assimilated parts around the core particles after cooling. Although it was reported that the viscosity of melt formed in fine mixture of pisolitic ore and limestone was low, ${ }^{8,9)}$ the viscosity of melt formed around coarse pisolitic ore particle in the present experiment was high because it consisted of large amount of granular hematite grains in a silicate matrix formed through incongruent melting of calcium ferrite phase, which formed by the reaction between fine hematite ore $\mathrm{B}$ and limestone, and assimilation of core particle into melt.

These results suggest if the viscosity of the melt decreases, formation of large pores will be able to suppress. The author ${ }^{3)}$ have reported that the viscosity of melt formed at $1220^{\circ} \mathrm{C}$ in a fine mixture of limestone and various iron ores increases with increase in the $\mathrm{CaO}$ concentration up to about 30 mass\%. Consequently, an increase in $\mathrm{CaO}$ concentration of the shell layer of pseudo-particles seems to be a method to lower the viscosity of the melt.

In the present study, sintering experiments were conducted using briquettes, of which disk-shaped pisolitic ore was used as a core particle, in order to evaluate the effects of an increase in $\mathrm{CaO}$ concentration of the shell layer and heating rate on the formation of the large pores existed in the assimilated parts of sinter. 


\section{Experimental}

\subsection{Preparation of Briquettes}

Pisolitic ore $\mathrm{R}$ from Australia, high grade hematite ore $\mathrm{B}$ from India and Japanese limestone were used as raw materials in the present experiment. Chemical composition and particle size of these materials are listed in Table 1. The value of LOI (Loss On Ignition) represents the ratio of weight loss during heating at $900^{\circ} \mathrm{C}$ for $1 \mathrm{~h}$ in $\mathrm{N}_{2}$ gas stream $\left(0.2 \mathrm{~cm}^{3} / \mathrm{min}\right)$.

A briquette, which consisted of disk-shaped ore $\mathrm{R}$ specimen as a core particle and fine mixture of ore $\mathrm{B}$ and limestone as a shell layer, was made under the pressure of $14.7 \mathrm{MPa}$. A schematic view of the modeled briquette is illustrated in Fig. 1. CaO concentration of the shell layer was varied in two levels, i.e., 10 and 26 mass $\%$ on the basis after calcination. The value of $26 \mathrm{mass} \% \mathrm{CaO}$ is corresponding to the composition of mono calcium ferrite $\left(\mathrm{CaO} \cdot \mathrm{Fe}_{2} \mathrm{O}_{3}\right)$, which forms in early stage of sintering process. ${ }^{10)}$ Chemical composition of fine mixtures on the basis after calcination are listed in Table 2. The composition of each mixture shows that it contains other components such as $\mathrm{Al}_{2} \mathrm{O}_{3}$ and $\mathrm{SiO}_{2}$ originated from the raw materials.

\subsection{Experimental Procedure}

Figure 2 shows a schematic diagram of the experimental apparatus. After setting a briquette in a platinum crucible (20 $\mathrm{mm}$ in inner diameter and $15 \mathrm{~mm}$ in height) at the center of infrared furnace, the briquette was heated up in air stream $\left(0.2 \mathrm{~cm}^{3} / \mathrm{min}\right)$ at different heating rates $\left(5,100\right.$, and $\left.200^{\circ} \mathrm{C} / \mathrm{min}\right)$. When the temperature was reached to a specified one, the briquette was quenched by blowing cold He gas $\left(0.04 \mathrm{~m}^{3} / \mathrm{min}\right)$ cooled through

Table 1. Chemical composition of raw materials. (mass \%)

\begin{tabular}{lcrllllll}
\hline $\begin{array}{c}\text { Raw } \\
\text { material }\end{array}$ & $\begin{array}{c}\text { Particle size } \\
(\mathrm{mm})\end{array}$ & $\mathrm{T} . \mathrm{Fe}$ & $\mathrm{FeO}$ & $\mathrm{CaO}$ & $\mathrm{SiO}_{2}$ & $\mathrm{Al}_{2} \mathrm{O}_{3}$ & $\mathrm{LOI}^{*}$ \\
\hline Ore R & +15 & 55.81 & 0.55 & 0.40 & 4.94 & 2.15 & 10.80 \\
Ore B & -0.105 & 67.10 & 0.66 & 0.92 & 0.95 & 2.80 & - \\
Limestone & -0.105 & 0.04 & - & 55.17 & 0.06 & 0.09 & - \\
\hline
\end{tabular}

* LOI (Loss on ignition)

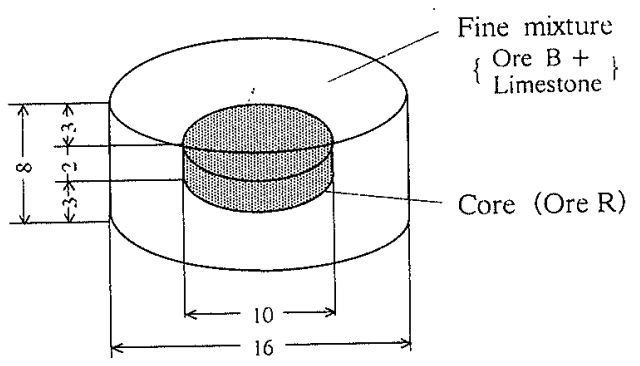

Fig. 1. Schematic view of specimen. (size in $\mathrm{mm}$ )

Table 2. Chemical composition of fine mixture. (mass \%)

\begin{tabular}{c|ccccc}
\hline CaO concentration & $\mathrm{Fe}_{2} \mathrm{O}_{3}$ & $\mathrm{FeO}$ & $\mathrm{CaO}$ & $\mathrm{SiO}_{2}$ & $\mathrm{Al}_{2} \mathrm{O}_{3}$ \\
\hline 10.0 & 85.9 & 0.6 & 10.0 & 0.8 & 2.5 \\
26.0 & 70.7 & 0.4 & 26.0 & 0.7 & 2.1 \\
\hline
\end{tabular}

liquid nitrogen. After the quenching operation, the specimen was embedded in epoxy-resin and cut and polished at its center. Then, it was subjected to microscopic observation, image analysis and quantitative analysis of mineral phase by EPMA. In the image analysis, the area fraction and the mean diameter of equivalent circle of pores existed in the assimilated part of the specimen were measured, but cracks existed in that part were excepted. The number of fields were about $10-15$ with the magnification of 100 on microscopy.

Temperature between inside and outside of a briquette seem to be different during heating because its size is not small enough to neglect an adiabatic effect of the shell layer and a heat sink due to melt formation. Therefore, temperature at inside of the briquette was tried to measure for different heating rates by inserting another thermocouple into the center of briquette. The thermocouple was covered by two-hole insulating tube at outside of briquette to prevent an excess increase in temperature. The results are shown in Fig. 3. Tem-

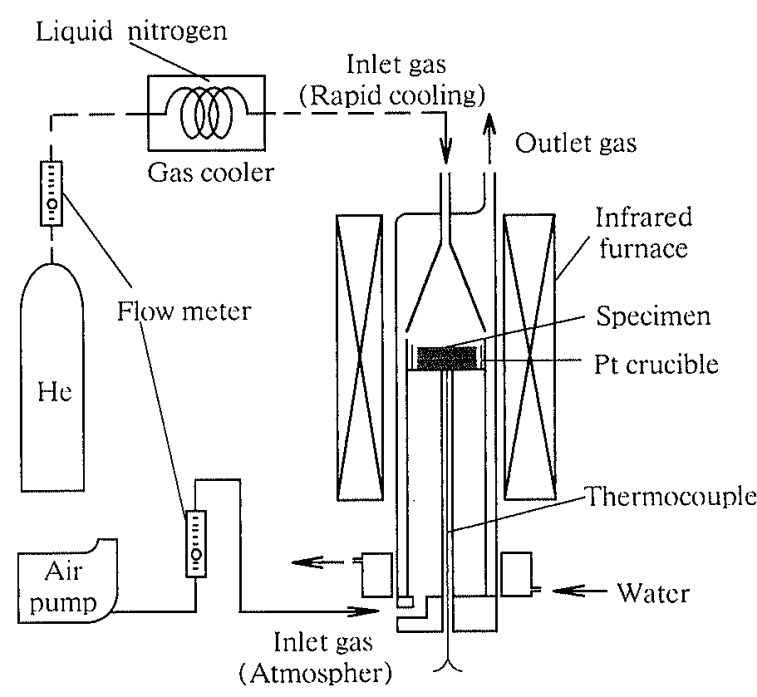

Fig. 2. Schematic diagram of experimental apparatus.

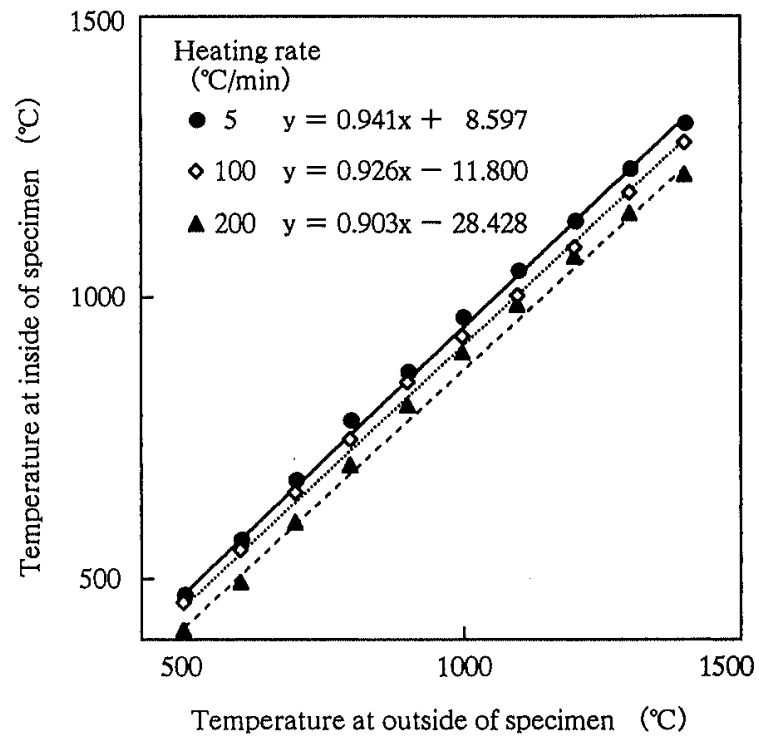

Fig. 3. Relation of temperature at outside and inside of specimen. 
perature at inside of briquette is lower than outside for any heating rate, but the relation between both temperatures are linear with fair reproducibility. Therefore, the temperature of the briquette was controlled by the thermocouple set at the outside of briquette and quenching temperature of the specimen was estimated from the linear regression between these temperatures. The equation of the linear regression at different heating rates is also shown in Fig. 3.

\section{Results}

Figure 4 shows microstructures at the vicinity of the core particle observed in specimens quenched at different temperatures during heating at a rate of $5^{\circ} \mathrm{C} / \mathrm{min}$. In the case quenched at $1210^{\circ} \mathrm{C}$, the assimilated part do not exist in any specimen having different $\mathrm{CaO}$ concentration. Calcium ferrite (CF) phase is observed with many pores in the shell layer (left side of the core) of both specimens and residual hematite particles are also obsedrved in the shell layer for the case of 10 mass $\%$ $\mathrm{CaO}$. A few cracks and micro-pores which seems to be formed by dissociation of combined water of ore $\mathrm{R}$ are observed in the core. A gap between the shell layer and core is also observed in both specimens. Pores existed in the shell layer are small for the case of $10 \mathrm{mass} \% \mathrm{CaO}$, whereas they are comparably large for 26 mass $\% \mathrm{CaO}$. It appears to be that the structural change in the shell layer caused by rearrangement of formed minerals and the coalescence of pores proceeds faster in the case of 26 mass $\% \mathrm{CaO}$ than that of 10 mass $\% \mathrm{CaO}$. For the specimens quenched at $1225^{\circ} \mathrm{C}$, the shell layer is fused in both specimens, and granular hematite particles are

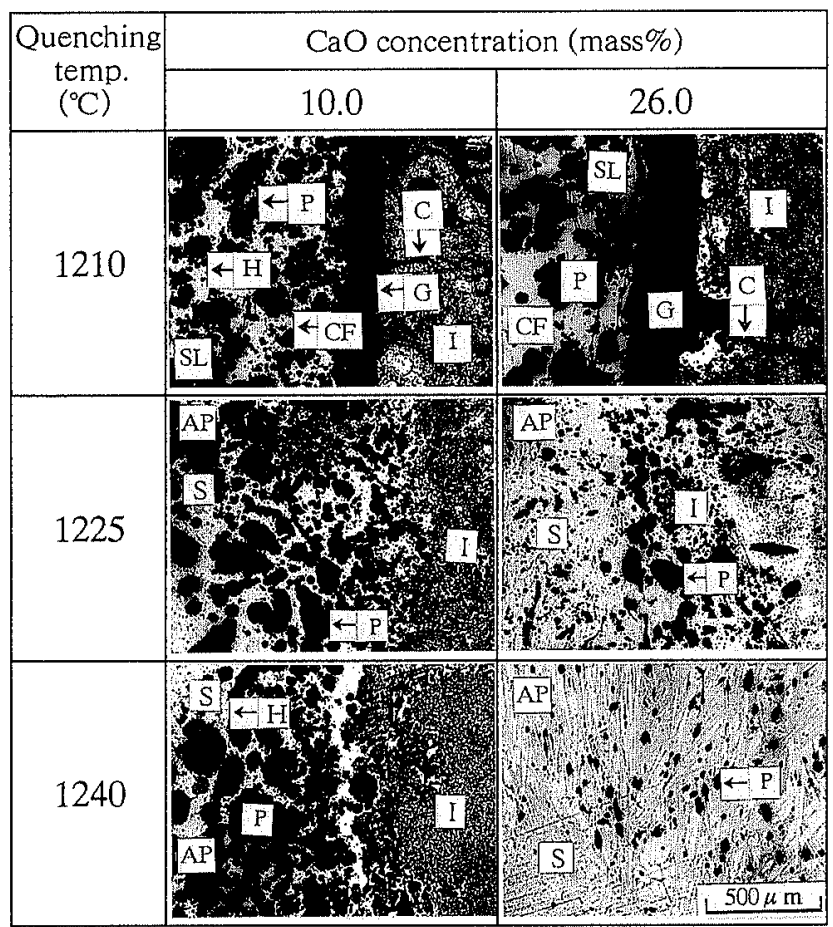

CF: Calcium ferrite, H: Hematite, P: Pore, C: Crack, S: Melt I: Core ore, G: Gap, SL: Shell layer, AP: Assimilated part

Fig. 4. Changes in microstructures of specimens quenched at different temperatures during heating at a rate of $5^{\circ} \mathrm{C} / \mathrm{min}$ also observed for the case of 10 mass $\% \mathrm{CaO}$. The core seems to start to assimilate with formed melt, since the boundary between the core and the fused part is not clear. It can be recognized that only a few pores exist in the assimilated part of the specimen with the shell layer of $26 \mathrm{mass} \% \mathrm{CaO}$, whereas numerous pores with wide size range exist for the case of 10 mass $\% \mathrm{CaO}$. In the case quenched at $1240^{\circ} \mathrm{C}$, the assimilation of the core proceeds further in both specimens and the core does not exist in the specimen with 26 mass $\% \mathrm{CaO}$, but the core still exists in the case of 10 mass $\% \mathrm{CaO}$. Microstructures of the assimilated part in both specimens suggest that a relatively homogeneous melt accompanying a few small pores forms in the specimen with 26 mass $\% \mathrm{CaO}$ because it composes mainly of columnar $\mathrm{CF}$, whereas a heterogeneous melt of granular hematite particles and silicate liquid accompanied by wide size range of pores forms in the case of 10 mass $\% \mathrm{CaO}$.

Figure 5 shows microstructures of specimen quenched at 1210 and $1240^{\circ} \mathrm{C}$ during heating at a rate of $100^{\circ} \mathrm{C} /$ min. Specimens quenched at $1210^{\circ} \mathrm{C}$ have similar structures to those with a heating rate of $5^{\circ} \mathrm{C} / \mathrm{min}$ (see Fig. 4). In the case quenched at $1240^{\circ} \mathrm{C}$, however, the shell layer already fuses and the core still remains in both specimens. Microstructures of the assimilated part are different depending on $\mathrm{CaO}$ concentration of the shell layer. It seems to be that formed melt is homogeneous for 26 mass $\% \mathrm{CaO}$, but it is heterogeneous having granular hematite particles for $10 \mathrm{mass} \% \mathrm{CaO}$. Further, a large number of pores with wide size range exist at the boundary between the core and assimilated part for both cases.

Figure 6 shows microstructures of specimen quenched at 1210 and $1240^{\circ} \mathrm{C}$ during heating at a rate of $200^{\circ} \mathrm{C} /$ min. Specimens quenched at each temperature have the almost same microstructures as those with a heating rate of $100^{\circ} \mathrm{C} / \mathrm{min}$ (see Fig. 5).

Figure 7 shows microstructures of quenched specimens in the course of a heating profile, namely two step

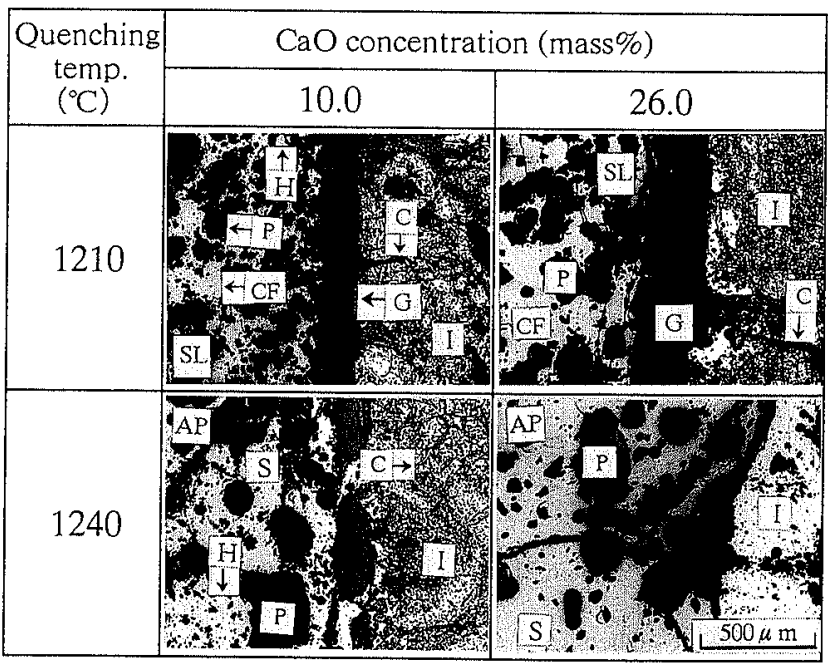

CF: Calcium ferrite, H: Hematite, P: Pore, C: Crack, S: Melt, I: Core ore, G: Gap, SL: Shell layer, AP: Assimilated part

Fig. 5. Changes in microstructures of specimens quenched at different temperatures during heating at a rate of $100^{\circ} \mathrm{C} / \mathrm{min}$. 


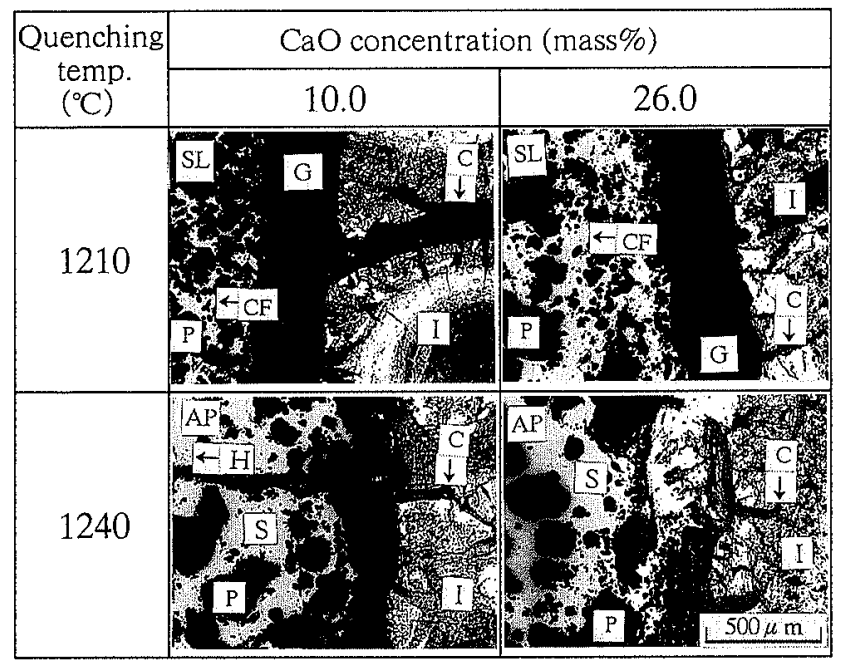

CF: Calcium ferrite, H: Hematite, P: Pore, C: Crack, S: Melt, I: Core ore, G: Gap, SL: Shell layer, AP: Assimilated part

Fig. 6. Changes in microstructures of specimens quenched at different temperatures during heating at a rate of $200^{\circ} \mathrm{C} / \mathrm{min}$.

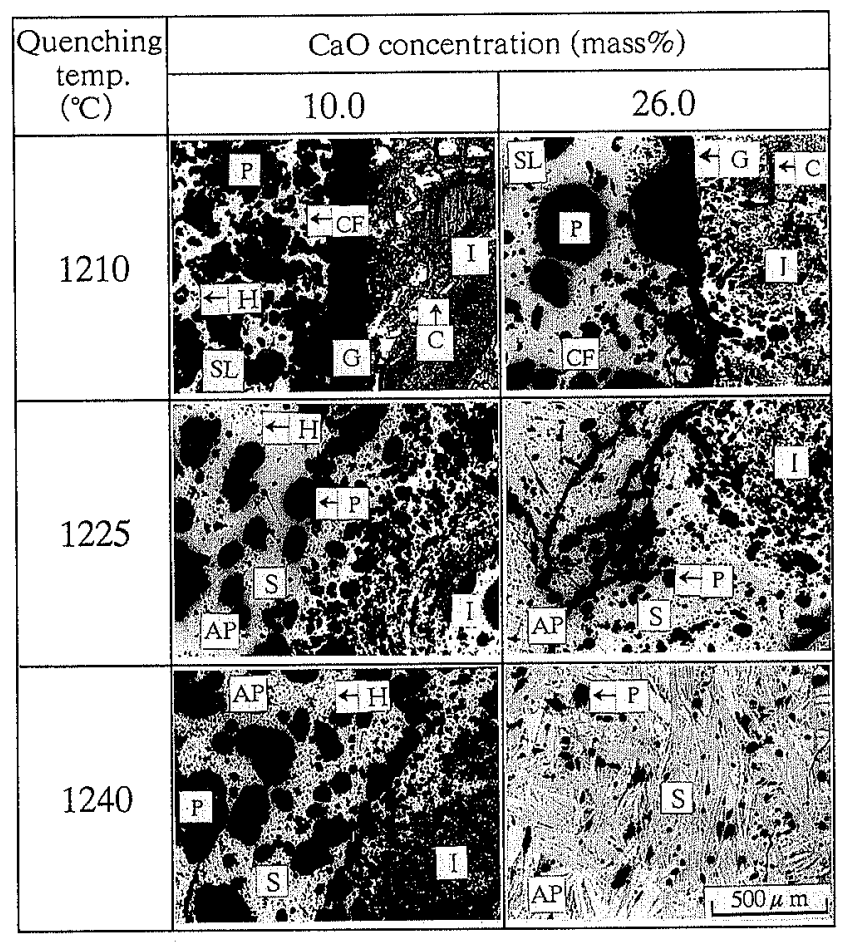

CF: Calcium ferrite, H: Hematite, P: Pore, C: Crack, S: Melt,

I: Core ore, G: Gap, SL: Shell layer, AP: Assimilated part

Fig. 7. Changes in microstructures of specimens quenched at different temperatures during heating at a rate of $100^{\circ} \mathrm{C} / \mathrm{min}$ (up to $1210^{\circ} \mathrm{C}$ ) and $5^{\circ} \mathrm{C} /$ min (over $\left.1210^{\circ} \mathrm{C}\right)$

heating, simulating to actual sintering process. The heating rate is $100^{\circ} \mathrm{C} / \mathrm{min}$ up to $1210^{\circ} \mathrm{C}$, and $5^{\circ} \mathrm{C} / \mathrm{min}$ over $1210^{\circ} \mathrm{C}$. The shell layer of specimen quenched at $1210^{\circ} \mathrm{C}$ does not fuse and the core having a few cracks remains in both specimens. This is similar to the case with a heating rate of $100^{\circ} \mathrm{C} / \mathrm{min}$ as shown in Fig. 5. The shell layers of both specimens quenched at $1225^{\circ} \mathrm{C}$ are already fused and assimilation of the core with formed melt seems to start since the boundary between the core and fused part is not clear. Existence state and size of

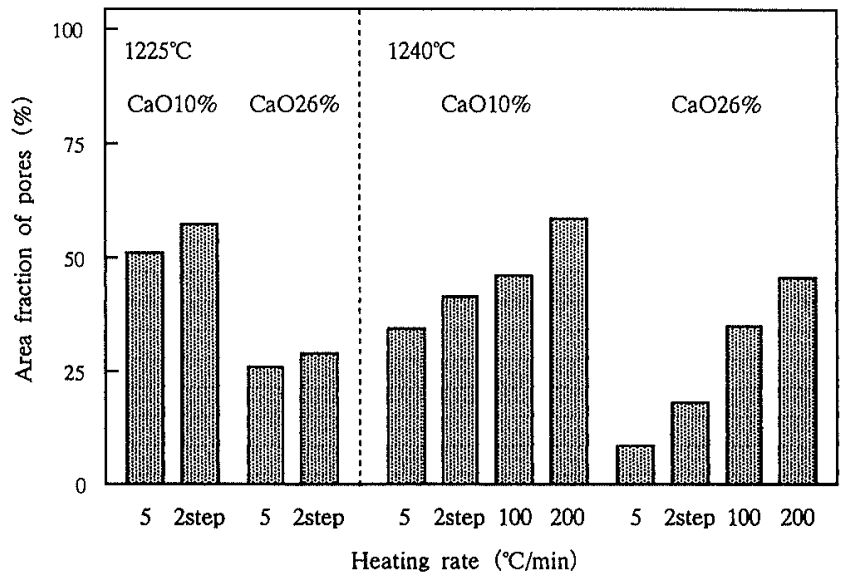

Fig. 8. Effect of heating rate and $\mathrm{CaO}$ concentration of the shell layer on the area fraction of pores in the assimilated part.

(2 step: $100^{\circ} \mathrm{C} / \mathrm{min}$ (up to $1210^{\circ} \mathrm{C}$ ), $5^{\circ} \mathrm{C} / \mathrm{min}$ (over $\left.\left.1210^{\circ} \mathrm{C}\right)\right)$

pores observed at assimilated part of both specimens are different depending on $\mathrm{CaO}$ concentration of the shell layer, i.e., numerous pores with wide size range exist at the assimilated part for 10 mass $\% \mathrm{CaO}$, whereas, for $26 \mathrm{mass} \% \mathrm{CaO}$, relatively large pores exist in only a limited region at the vicinity of the core surface and pores in the assimilated part are very small. In the case quenched at $1240^{\circ} \mathrm{C}$, numerous large pores exist in the assimilated part for 10 mass $\% \mathrm{CaO}$ while the assimilation of the core seems to be completed and only a few small pores exist for 26 mass $\% \mathrm{CaO}$. These structural changes are almost same as the case with heating rate of $5^{\circ} \mathrm{C} / \mathrm{min}$ (see Fig. 4).

The area fraction and the mean diameter of equivalent circle of pores existed in the assimilated part of the specimens quenched over $1225^{\circ} \mathrm{C}$ were measured by an image analyzer, because assimilated part can be observed for all specimens quenched over $1225^{\circ} \mathrm{C}$ independent of $\mathrm{CaO}$ concentration of the shell layer as mentioned above.

Figure $\mathbf{8}$ shows the area fraction of pores measured for different specimens. The value of area fraction is significantly varied with heating rate, quenching temperature and $\mathrm{CaO}$ concentration of the shell layer. Comparing at the same heating rate, the area fraction for 10 mass $\% \mathrm{CaO}$ is higher than that for 26 mass $\%$ $\mathrm{CaO}$ at any quenching temperature. For the both $\mathrm{CaO}$ concentration, the area fraction increases with increase in heating rate. Since the value for $1240^{\circ} \mathrm{C}$ is lower than that for $1225^{\circ} \mathrm{C}$, coalescence of bubbles which would exist as pores after cooling and their remove-out from the assimilated part is observed to proceed more in higher temperature. Furthermore, the area fraction is higher for the two step heating than that for heating rate of $5^{\circ} \mathrm{C} / \mathrm{min}$ and is lower than that for heating rate of $100^{\circ} \mathrm{C} / \mathrm{min}$. This means that the amount of pores existed in the assimilated parts is also influenced by the heating rate over the temperature which melt starts to form.

Figure 9 shows the change in the mean diameter of equivalent circle of pores with the heating rate, quenching temperature and $\mathrm{CaO}$ concentration of the shell 


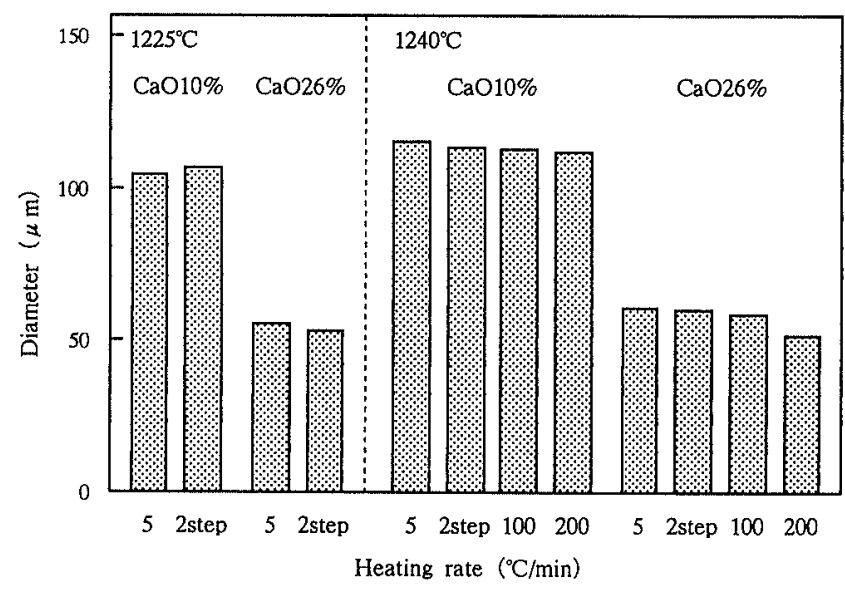

Fig. 9. Effect of heating rate and $\mathrm{CaO}$ concentration of the shell layer on the mean diameter of equivalent circle of pores in the assimilated part.

(2 step: $100^{\circ} \mathrm{C} / \mathrm{min}$ (up to $1210^{\circ} \mathrm{C}$ ), $5^{\circ} \mathrm{C} / \mathrm{min}$ (over $\left.1210^{\circ} \mathrm{C}\right)$ )

layer. It is obvious that the diameter of pores varied with $\mathrm{CaO}$ concentration of shell layer for any quenching temperatures, i.e., the value for 26 mass $\% \mathrm{CaO}$ was about a half of that for 10 mass $\% \mathrm{CaO}$. However, both of heating rate and quenching temperature do not much affect on the diameter of pores. These results suggest that the size of movable bubble in and through the assimilated part depends on $\mathrm{CaO}$ concentration of the shell layer. Pores formed in the case of $26 \mathrm{mass} \% \mathrm{CaO}$ is easier to move in the assimilated part than that of 10 mass $\% \mathrm{CaO}$.

According to the results shown in Figs. 8 and 9, increase of $\mathrm{CaO}$ concentration of the shell layer from 10 to $26 \mathrm{mass} \%$ leads to decrease in both of amount and size of pores existed in the assimilated part due to decrease in the volume of movable bubble in and through formed melt. Further, it can be pointed out that lower heating rate at high temperature also leads to decrease in the amount of pores.

\section{Discussion}

It is clear from microstructures shown in Figs. 4 to 7 that formation of melt in briquette is mainly caused by incongruent melting of $\mathrm{CF}$ formed in the shell layer during heating. Therefore the melting temperature of $\mathrm{CF}$ phases in the specimens having different $\mathrm{CaO}$ concentration is an important factor which influences existing state of pores formed in the assimilated parts as well as viscosity of the melt.

Table 3 shows chemical composition of the melted parts, which solidify as $\mathrm{CF}$ phases, in the specimens quenched at $1225^{\circ} \mathrm{C}$ during heating at a rate of $5^{\circ} \mathrm{C} / \mathrm{min}$. Obtained chemical composition of $\mathrm{CF}$ correspond to that of mono-CF $\left(\mathrm{CaO} \cdot \mathrm{Fe}_{2} \mathrm{O}_{3}\right)$ and hemi-CF $(\mathrm{CaO}$. $2 \mathrm{Fe}_{2} \mathrm{O}_{3}$ ) for specimens of 26 and 10 mass $\% \mathrm{CaO}$, respectively. From phase diagram of $\mathrm{CaO}-\mathrm{Fe}_{2} \mathrm{O}_{3}$ system $^{11)}$ shown in Fig. 10, however, it is found that the difference of the melting temperatures between monoand hemi-CFs is only $10^{\circ} \mathrm{C}$, since the melting temperature of mono-CF and hemi-CF is 1216 and $1226^{\circ} \mathrm{C}$, respectively. CF observed in the both specimens in the present
Table 3. Chemical composition of calcium ferrite phase observed in specimens quenched at $1225^{\circ} \mathrm{C}$ during heating at a rate of $5 \mathrm{C} / \mathrm{min}$. (mass\%)

\begin{tabular}{c|cccc}
\hline CaO concentration & $\mathrm{CaO}$ & $\mathrm{SiO}_{2}$ & $\mathrm{Al}_{2} \mathrm{O}_{3}$ & $\mathrm{Fe}_{2} \mathrm{O}_{3}$ \\
\hline 10.0 & 14.58 & 2.48 & 1.72 & 81.23 \\
26.0 & 25.32 & 1.90 & 1.24 & 71.54 \\
\hline
\end{tabular}

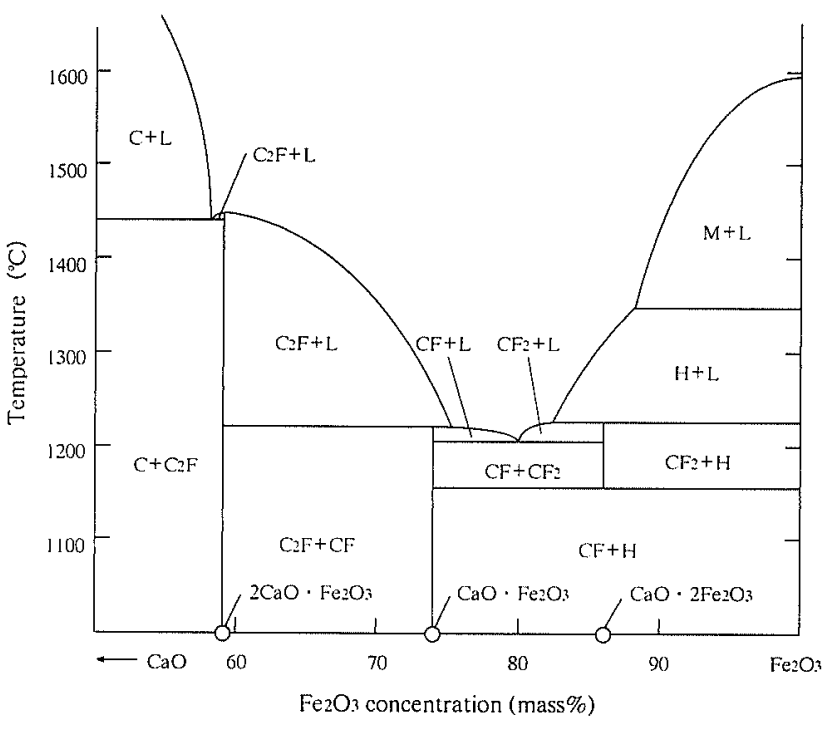

Fig. 10. Phase diagram of $\mathrm{CaO}-\mathrm{Fe}_{2} \mathrm{O}_{3}$ system. $^{8)}$

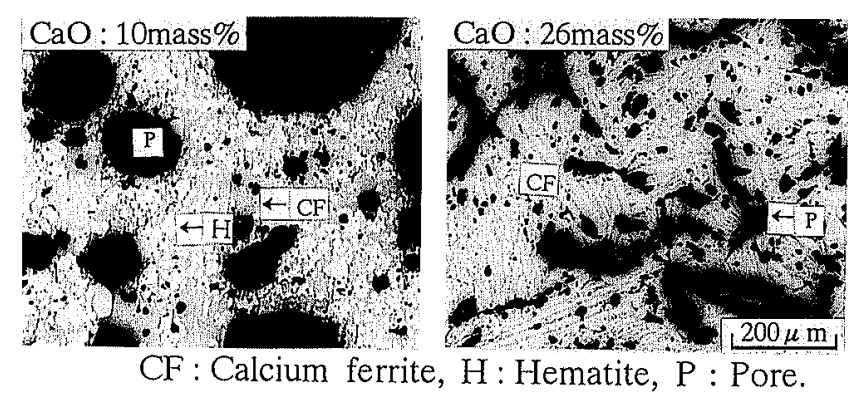

Fig. 11. Typical microstructures of assimilated part observed in specimens quenched at $1225^{\circ} \mathrm{C}$ during heating at a rate of $5^{\circ} \mathrm{C} / \mathrm{min}$.

study is not a binary system of $\mathrm{CaO}$ and $\mathrm{Fe}_{2} \mathrm{O}_{3}$ but multi-components including $\mathrm{Al}_{2} \mathrm{O}_{3}$ and $\mathrm{SiO}_{2}$ and their composition are different as shown in Table 3 . Although some studies are reported ${ }^{12-14)}$ about influences of $\mathrm{Al}_{2} \mathrm{O}_{3}$ and $\mathrm{SiO}_{2}$ components on the melting behavior of quaternary $\mathrm{CF}$, those results have not given sufficient information to estimate a phase diagram of the quaternary system. Therefore the melting temperatures of $\mathrm{CF}$ observed in the present study is not clear. However, the difference of melting temperature of observed CF seems to be small since the melt-formation in both the specimens starts at the temperature range between 1210 and $1225^{\circ} \mathrm{C}$ independent of $\mathrm{CaO}$ concentration of the shell layer (see Figs. 4 and 7). Hence, incongruent melting temperature of $\mathrm{CF}$ will not be a significant factor affecting the existing state of pores formed in the assimilated parts of sinter.

Figure 11 shows microstructures of the assimilated part of the specimen quenched at $1225^{\circ} \mathrm{C}$ during heating at a rate of $5^{\circ} \mathrm{C} / \mathrm{min}$. It can be estimated that the melt 
formed in the specimen of 10 mass $\% \mathrm{CaO}$ contains solid particles of secondary hematite, whereas that of 26 mass \% $\mathrm{CaO}$ is fairly homogeneous because only $\mathrm{CF}$ phase is observed after quenching. It suggests that the apparent viscosity of the melt formed in the specimen of 26 mass $\% \mathrm{CaO}$ is relatively lower than that of 10 mass $\%$ $\mathrm{CaO}$.

It is thought to be appropriate that the reason of the smaller values in both the diameter and amount of pores in the assimilated part of the specimen for 26 mass $\%$ $\mathrm{CaO}$ than that for 10 mass\% $\mathrm{CaO}$ can be ascribed to the lower apparent viscosity of the formed melt. The apparent viscosity of the melt influences the moving performance of bubbles in the melt. Hence, it is concluded that the formation of large pores in the assimilated parts can be suppressed by both of the promotion of the coalescence of bubbles and the decrease in the bubble size possible to move in the melt due to lowering the apparent viscosity of the melt by increase in $\mathrm{CaO}$ concentration of the shell layer. Further, formation of large pores may also be suppressed by a prolongation of the time in high temperature.

Taking account of the results, it may be worth to mention that the segregation of $\mathrm{CaO}$ component in raw mixtures, e.g., the separated graulation method, ${ }^{15}$ is one of the appropriate ways to use a large amount of pisolitic ores. Even in such cases, preparation of pseudo-particles which consist of pisolitic ore particles as cores and adhering layers having high $\mathrm{CaO}$ content is a key for particularly maintaining product yield and strength of sinter. Further studies such as sintering-pot and reduction-properties tests are necessary to examine an applicability of the present findings to the actual sintering process.

\section{Conclusion}

In order to suppress the formation of large pores in the assimilated parts of sinter produced using pisolitic ore as core of pseudo-particles, sinering experiments were carried out to examine the influence of $\mathrm{CaO}$ concentration in the shell layer of modeled pseudo-particle and heating rate. The results obtained were summarized as follows:
(1) By increasing $\mathrm{CaO}$ concentration in the shell layer from 10 to 26 mass \%, the formation of large pores can be suppressed and both the diameter and amount of pores remained in the assimilated part decrease significantly.

(2) The amount of pores decreased with decrease in heating rate over the temperature which melt starts to form, but heating rate did not influence remarkably pore diameter.

(3) It is clear that the suppressible effect for the formation of large pores by increasing $\mathrm{CaO}$ concentration of the shell layer is caused by both of the promotion of coalescence of bubbles and decrease in the bubble size possible to move in the melt due to lowering apparent viscosity of the melt formed during heating.

\section{Acknowledgment}

The financial support by the Japan Association of Chemistry to a part of the present study is gratefully acknowledged.

\section{REFERENCES}

1) N. Nishida: Tetsu-to-Hagané, 67 (1981), 1677.

2) Y. Hida and Y. Nosaka: Tetsu-to-Hagané, 78 (1992), 960

3) E. Kasai, S. Wu and Y. Omori: Tetsu-to-Hagané, 77 (1991), 56.

4) Y. Hida, J. Okazaki, K. Ito and S. Hirakawa: Tetsu-to-Hagané, 78 (1992), 1013

5) Y. Hida, K. Ito, J. Okazaki, M. Sasaki and Y. Umezu: Tetsu-toHagané, 68 (1982), 2166.

6) S. Sato, T. Kawaguchi, M. Ichidate and M. Yoshinaga: Tetsu-toHagané, 73 (1987), 804.

7) T. Otomo, N. Taguchi, E. Kasai, Y. Omori and T. Kawaguchi: Tetsu-to-Hagané, 79 (1993), 1145.

8) Y. Nosaka, S. Isozaki and K. Sugawara: Tetsu-to-Hagané, 67 (1981), S655

9) T. Matsumura, J. Kiguchi and M. Shimizu: CAMP-ISIJ, 8 (1995), 860.

10) M. Sasaki and Y. Hida: Tetsu-to-Hagané, 68 (1982), 563.

11) B. Phillips and A. Muan: J. Am. Ceram. Soc., 41 (1958), 445.

12) C. K. Yang, T. Shoji and S. Takenouchi: J. Min. Metall. Inst. Jpn., 94 (1978), 575 .

13) K. Inoue and T. Ikeda: Tetsu-to-Hagané, 68 (1982), 2190.

14) T. Otomo and N. Taguchi: Sci. Tech. Rep. Mining College, Akita Univ., 11 (1990), 1.

15) T. Kawaguchi, K. Kuriyama, S. Sato and K. Takata: Tetsu-toHagané, 73 (1987), 1924. 